\title{
Zróżnicowanie zbiorowisk leśnych obszaru Natura 2000 „Las Hrabeński” na Pogórzu Bukowskim (Karpaty Zachodnie)
}

\author{
TOMASZ WÓJCIK i MARIA ZiAJA
}

\begin{abstract}
WóJciK, T. AND Ziaja, M. 2020. Differentiation of forest communities in the Las Hrabeński Natura 2000 area in the Pogórze Bukowskie foothills (Western Carpathians). Fragmenta Floristica et Geobotanica Polonica 27(x): 409-422. Kraków. e-ISSN 2449-8890, ISSN 1640-629X.

ABSTRACT: The study characterises the forest communities in the Las Hrabeński PLH 180039 Natura 2000 area. The study site, with an area of 125.6 ha, is in the Pogórze Bukowskie foothills (Western Carpathians) in the southern part of Podkarpackie Province. In 2019, 30 phytosociological relevés were made using the Braun-Blanquet method. Analysis of the relevés showed the presence of three subassociations: Tilio-Carpinetum typicum, Dentario glandulosae-Fagetum typicum and Dentario glandulosae-Fagetum lunarietosum. The identified plant communities are in good condition due to having many characteristic species and high general species richness. Additionally, protected and ancient woodland plant species were found in these communities.
\end{abstract}

KEY WORDS: characteristic species, Dentario glandulosae-Fagetum, phytosociological relevés, Poland, subassociations, Tilio-Carpinetum

T. Wójcik, Zakład Ochrony Przyrody i Ekologii Krajobrazu, Uniwersytet Rzeszowski, ul. Zelwerowicza 4, 35-601 Rzeszów, Polska; e-mail: antomi7@wp.pl

M. Ziaja, Instytut Nauk o Kulturze Fizycznej, Uniwersytet Rzeszowski, ul. Cicha 2A, 35-326

Rzeszów,Polska; e-mail: mziaja@ur.edu.pl

\section{WSTĘP}

Badania nad poznaniem zróżnicowania zbiorowisk leśnych Pogórza Karpackiego rozwinęły się w drugiej połowie XX w. Większość dotychczasowych opracowań obejmuje pogórską część Karpat Zachodnich. Należą do nich m.in. prace z Pogórzy: Wielickiego (MEDWECKA-KorNAŚ i in. 1988; RóŻAŃSKI i in. 1987, 1993; STACHURSKA 1995, 1998), Strzyżowskiego (TowPasz 1990; Towpasz \& Stachurska-Swakoń 2008, 2010; WójciK \& Ziaja 2017), Ciężkowickiego (MedweCKa-Kornaś 1976), Dynowskiego (WósciK \& Ziaja 2015; WóJCIK i in. 2016), Przemyskiego (KozŁowsKa 2000), a także z Beskidu Niskiego (TACiK i in. 1957; Grodzińska \& PANCER-Kotejowa 1965; StasZKiewicz 1973; Świes 1982a, b; MichaliK 2009). Natomiast z terenu Karpat Wschodnich znane są opracowania: DzWONKI (1977) oraz Dzwonki i ZemanKa (1976) z Gór Słonnych.

Nadal jednak wiele części Pogórza nie zostało dostatecznie zbadanych w tym aspekcie. Należy do nich Pogórze Bukowskie będące mezoregionem najdalej wysuniętym na wschód 
w obrębie Karpat Zachodnich. Położenie na granicy dwóch dużych prowincji karpackich (Karpaty Zachodnie z Podkarpaciem, Karpaty Wschodnie) jest interesujące z geobotanicznego punktu widzenia, gdyż wpływa na przejściowy charakter szaty roślinnej, co można zaobserwować w przypadku zbiorowisk leśnych. Odzwierciedleniem tego jest występowanie różnych odmian grądów reprezentowanych przez zespół Tilio-Carpinetum oraz buczyn należących do zespołu Dentario glandulosae-Fagetum. Jednym z bardziej interesujących, pod kątem geobotanicznym, terenów Pogórza Bukowskiego jest Las Hrabeński, będący zarazem obszarem Natura 2000, w którym dzięki urozmaiconej rzeźbie można spotkać wszystkie główne typy zbiorowisk leśnych mezoregionu.

Głównym celem pracy jest przedstawienie zróżnicowania oraz ocena stanu zachowania zbiorowisk leśnych obszaru Natura 2000 Las Hrabeński.

\section{TEREN BADAŃ}

Las Hrabeński w ujęciu fizycznogeograficznym należy do mezoregionu Pogórza Bukowskiego (KONDRACKI 2011). Zlokalizowany jest on w południowej części województwa podkarpackiego, na zachód od Beska (Ryc. 1) i zajmuje wzgórza rozciągające się między doliną Wisłoka na wschodzie, a rzeką Tabor na zachodzie. Jest to stosunkowo niewielki, izolowany kompleks leśny o powierzchni 125,6 ha (ŁUCZAJ 2011). Deniwelacje terenu dochodzą do 100 m. Najwyżej położony punkt (391 m n.p.m.) znajduje się w południowo-zachodniej części, najniższy (290 m n.p.m.) leży w dolinie potoku po stronie północnej. Na obszarze

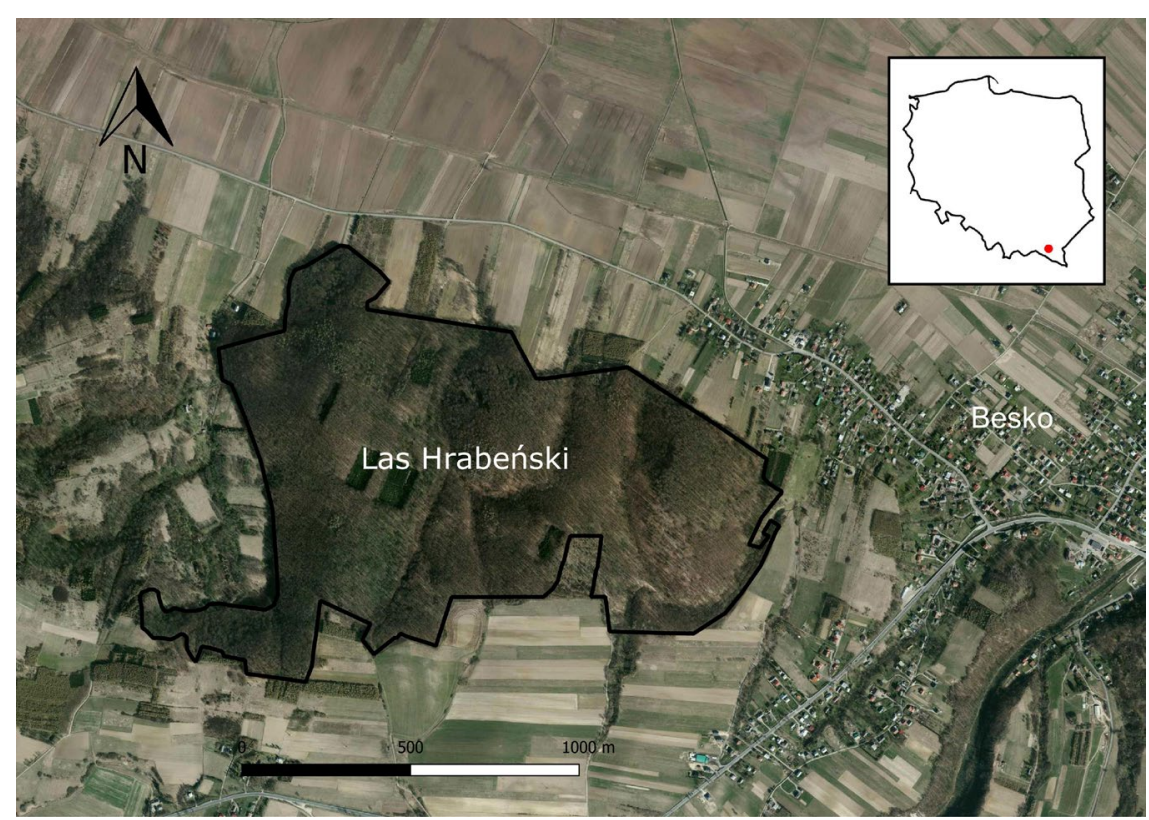

Ryc. 1. Teren badań

Fig. 1. Study area 
tym możemy wyróżnić wypłaszczoną wierzchowinę oraz stoki o różnym stopniu nachylenia i zróżnicowanej ekspozycji, co ma znaczący wpływ na miejscową szatę roślinną, którą tworzą w dużej mierze zbiorowiska leśne o charakterze przejściowym między grądem a buczyną.

Las Hrabeński to zarazem obszar Natura 2000, który został powołany w celu ochrony dobrze zachowanego ekosystemu leśnego obejmującego trzy siedliska przyrodnicze z Załącznika I Dyrektywy Siedliskowej (DYREKTYwA 1992): 9170 grąd subkontynentalny Tilio-Carpinetum, 9130 żyzna buczyna karpacka Dentario glandulosae-Fagetum, 9180 jaworzyna z miesiącznicą trwałą Lunario-Aceretum (ŁUCZAJ 2011).

\section{MATERIAE I METODY}

W 2019 r. przeprowadzono badania fitosocjologiczne metodą BRAUN-BlANQUETA (1964). Zdjęcia fitosocjologiczne o powierzchni $100 \mathrm{~m}^{2}$ każde, wykonano w trzech typach siedlisk przyrodniczych obszaru Natura 2000 „Las Hrabeński”: 1) grądzie subkontynentalnym zajmującym najniższe lekko nachylone stoki, 2) żyznej buczynie karpackiej porastającej wyższe i umiarkowanie nachylone stoki oraz 3) buczynie rozwiniętej na najbardziej stromych stokach w południowo-zachodniej części kompleksu leśnego (w sumie 30 zdjęć). Przy wyborze lokalizacji płatów do zdjęć najważniejszym kryterium była jednolitość fitocenozy (DZWONKo 2007).

Klasyfikację syntaksonomiczną przeprowadzono na podstawie MATUSZKIEWICZA (2001) oraz opracowań o charakterze regionalnym (DzWONKo 1977, 1986; TowPASZ \& STACHURSKA-SwaKoń 2010). Nomenklaturę roślin naczyniowych podano za MiRKIEM i in. (2002), gatunki objęte prawną ochroną wyszczególniono zgodnie z Rozporządzeniem Ministra Środowiska (RozPORZĄDZENIE 2014), natomiast gatunki wskaźnikowe dla starych lasów według Dzwonko i Loster (2001).

\section{WYNIKI BADAŃ}

Na podstawie analizy 30 zdjęć fitosocjologicznych stwierdzono występowanie trzech zbiorowisk roślinnych w randze podzespołów: Tilio-Carpinetum typicum, Dentario glandulosae-Fagetum typicum i Dentario glandulosae-Fagetum lunarietosum (Tab. 1, 2).

W badanym kompleksie leśnym grąd subkontynentalny rozwinął się w niższej części wzgórz, na lekko nachylonych stokach $\left(2-3^{\circ}\right)$. Pod względem rzeźby obszar ten obfituje we wklęsłe formy terenu jak parowy i debrza, a także holwegi powstałe w wyniku działalności człowieka. Warstwa drzew osiągała pokrycie od 70 do 95\% (średnio 88\%). Dominował w niej Carpinus betulus z domieszką: Acer pseudoplatanus, A. campestre, Ulmus laevis i Tilia cordata. Warstwa krzewów była bujna, a jej średnie pokrycie wynosiło 34\%; budowały ją podrosty drzew, a także liczne krzewy: Sambucus nigra, Daphne mezereum, Padus avium, Lonicera xylosteum, Corylus avellana. Warstwa zielna była dobrze wykształcona, a jej średnie pokrycie wynosiło $91 \%$. W całym zbiorowisku odnotowano łącznie 57 gatunków roślin naczyniowych (od 28 do 40 gatunków w zdjęciach, średnio 34) (Tab. 1). Liczne były gatunki charakterystyczne dla zespołu Tilio-Carpinetum, np. Ranunculus cassubicus i Carex pilosa oraz charakterystyczne dla związku Carpinion betuli - Stellaria holostea i Dactylis polygama, co spowodowało, iż omawianą jednostkę sklasyfikowano w randze podzespołu Tilio-Carpinetum typicum. Ponieważ grąd Lasu Hrabeńskiego sąsiaduje z wyżej 
Tabela 1. Podzespół Tilio-Carpinetum typicum

Table 1. Subassociation Tilio-Carpinetum typicum

\begin{tabular}{|c|c|c|c|c|c|c|c|c|c|c|c|}
\hline $\begin{array}{l}\text { Numer kolejny zdjęcia } \\
\text { (Succesive number od relevé) }\end{array}$ & 1 & 2 & 3 & 4 & 5 & 6 & 7 & 8 & 9 & 10 & \multirow{10}{*}{ 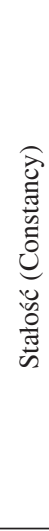 } \\
\hline Data (Date) & \multicolumn{10}{|c|}{ 14.06.2019 } & \\
\hline Powierzchnia (Area of relevé) $\left[\mathrm{m}^{2}\right]$ & 100 & 100 & 100 & 100 & 100 & 100 & 100 & 100 & 100 & 100 & \\
\hline Ekspozycja (Exposition) & $\mathrm{N}$ & NW & $\mathrm{NE}$ & NE & $\mathrm{N}$ & $\mathrm{NE}$ & $\mathrm{NE}$ & $\mathrm{NE}$ & NE & NE & \\
\hline Nachylenie (Slope) $\left[{ }^{\circ}\right]$ & 2 & 2 & 2 & 2 & 3 & 2 & 2 & 2 & 3 & 3 & \\
\hline Wysokość n.p.m. (Altitude) [m a.s.1.] & 248 & 254 & 262 & 284 & 299 & 297 & 299 & 310 & 314 & 314 & \\
\hline $\begin{array}{l}\text { Pokrycie warstwy drzew a } \\
\text { (Cover of tree layer) [\%] }\end{array}$ & 80 & 95 & 95 & 95 & 70 & 80 & 90 & 95 & 80 & 98 & \\
\hline $\begin{array}{l}\text { Pokrycie warstwy krzewów b } \\
\text { (Cover of shrub layer) [\%] }\end{array}$ & 30 & 30 & 10 & 40 & 30 & 50 & 60 & 30 & 40 & 20 & \\
\hline $\begin{array}{l}\text { Pokrycie warstwy zielnej } \\
\text { (Herb layer cover) }[\%]\end{array}$ & 100 & 98 & 100 & 90 & 90 & 100 & 95 & 80 & 90 & 70 & \\
\hline Liczba gatunków (Number of species) & 37 & 40 & 36 & 35 & 31 & 31 & 36 & 33 & 30 & 28 & \\
\hline \multicolumn{12}{|l|}{$\begin{array}{l}\text { Drzewa i krzewy (trees and shrubs): } \\
\text { Ch.All. Carpinion betuli }\end{array}$} \\
\hline Carpinus betulus a & 4 & 4 & 5 & 5 & 3 & 2 & 3 & 3 & 5 & 5 & \multirow{2}{*}{$\mathrm{V}$} \\
\hline Carpinus betulus b & . & + & . & . & . & 1 & . & . & . & . & \\
\hline $\begin{array}{l}\text { Tilia cordata b } \\
\text { Ch.All. Fagion sylvaticae }\end{array}$ & 1 & + & + & 1 & 2 & 2 & 1 & + & 1 & 1 & $\mathrm{~V}$ \\
\hline Fagus sylvatica b & 1 & 2 & 1 & 1 & 1 & 1 & 2 & 2 & 3 & 2 & $\mathrm{~V}$ \\
\hline Ch.All. Tilio platyphylli-Acerion pseudoplatani & & & & & & & & & & & \\
\hline Acer pseudoplatanus a & 1 & 2 & 1 & . & . & 2 & 2 & 2 & . & . & \\
\hline Acer pseudoplatanus b & . & + & . & 2 & 1 & 1 & 1 & 1 & 1 & 1 & $\mathrm{~V}$ \\
\hline Acer pseudoplatanus c & + & + & + & . & + & . & . & . & . & 2 & \\
\hline Ch.O. Fagetalia sylvaticae & & & & & & & & & & & \\
\hline Ulmus laevis a & . & . & . & . & . & 1 & 2 & . & . & . & I \\
\hline Daphne mezereum b & + & + & + & 1 & . & . & . & + & + & + & IV \\
\hline Padus avium b & . & + & . & . & . & 2 & . & 1 & . & . & II \\
\hline Ch.Cl. Querco-Fagetea & & & & & & & & & & & \\
\hline Fraxinus excelsior b & + & + & + & + & . & . & + & . & + & . & III \\
\hline Lonicera xylosteum b & + & + & + & 1 & . & . & 1 & 1 & . & . & III \\
\hline Corylus avellana b & 1 & . & . & . & . & . & 1 & . & . & . & I \\
\hline $\begin{array}{l}\text { Rośliny zielne (Herbs): } \\
\text { Ch.Ass. Tilio-Carpinetum }\end{array}$ & & & & & & & & & & & \\
\hline Ranunculus cassubicus & + & 1 & + & + & + & + & + & + & + & 1 & V \\
\hline Carex pilosa & . & + & . & . & . & . & . & . & + & 2 & II \\
\hline Ch.All. Carpinion betuli & & & & & & & & & & & \\
\hline Stellaria holostea & 1 & 2 & 2 & 2 & 3 & 3 & 2 & 2 & 3 & 1 & $\mathrm{~V}$ \\
\hline Dactylis polygama & 1 & + & 1 & + & + & + & 1 & + & 1 & + & $\mathrm{V}$ \\
\hline Ch.All. Fagion sylvaticae & & & & & & & & & & & \\
\hline Symphytum cordatum & 1 & + & . & . & . & . & . & . & . & . & I \\
\hline Ch.O. Fagetalia sylvaticae & & & & & & & & & & & \\
\hline Galeobdolon luteum & 2 & 2 & 1 & 2 & 2 & 1 & 2 & 1 & 2 & 2 & $\mathrm{~V}$ \\
\hline Pulmonaria obscura & 2 & 2 & 2 & 2 & 2 & 1 & 2 & 1 & 1 & 1 & $\mathrm{~V}$ \\
\hline Lilium martagon & 1 & 3 & 1 & 1 & 1 & 1 & 1 & 1 & 1 & 2 & $\mathrm{~V}$ \\
\hline
\end{tabular}


Tabela 1. Kontynuacja - Table 1. Continued

\begin{tabular}{|c|c|c|c|c|c|c|c|c|c|c|c|}
\hline $\begin{array}{l}\text { Numer kolejny zdjęcia } \\
\text { (Succesive number od relevé) }\end{array}$ & 1 & 2 & 3 & 4 & 5 & 6 & 7 & 8 & 9 & 10 & $\mathrm{~S}(\mathrm{C})$ \\
\hline Asarum europaeum & 1 & 1 & 2 & 1 & + & 1 & 1 & 1 & 1 & 1 & $\mathrm{~V}$ \\
\hline Milium effusum & 1 & + & + & + & 1 & 1 & + & + & + & + & $\mathrm{V}$ \\
\hline Polygonatum multiflorum & + & + & + & 1 & + & + & + & + & 1 & 1 & $\mathrm{~V}$ \\
\hline Primula elatior & 2 & 1 & 1 & 1 & 1 & + & + & . & 1 & 1 & $\mathrm{~V}$ \\
\hline Astrantia major & 2 & 2 & 2 & + & + & + & + & 1 & . & + & $\mathrm{V}$ \\
\hline Aposeris foetida & + & + & + & + & 1 & . & + & 1 & 2 & 1 & $\mathrm{~V}$ \\
\hline Euphorbia amygdaloides & 1 & + & 1 & + & + & . & + & 1 & + & + & $\mathrm{V}$ \\
\hline Ranunculus lanuginosus & + & + & + & + & + & + & 1 & 1 & + & . & $\mathrm{V}$ \\
\hline Galium odoratum & . & 2 & 2 & 2 & 1 & + & . & 2 & 2 & + & IV \\
\hline Circaea lutetiana & 1 & + & . & + & + & + & + & + & + & . & IV \\
\hline Stachys sylvatica & 1 & + & 1 & + & . & 2 & 1 & . & . & . & III \\
\hline Paris quadrifolia & . & + & + & 1 & . & + & + & + & . & . & III \\
\hline Carex sylvatica & + & . & + & . & + & + & . & . & + & + & III \\
\hline Lathyrus vernus & . & . & . & + & + & . & . & + & . & . & II \\
\hline \multicolumn{12}{|l|}{ Ch.Cl. Querco-Fagetea } \\
\hline Aegopodium podagraria & 2 & 2 & 2 & 2 & 2 & 3 & 2 & 2 & . & . & IV \\
\hline Melica nutans & + & + & + & . & 2 & + & 1 & . & 1 & 1 & IV \\
\hline Anemone nemorosa & 1 & + & + & . & 1 & . & + & . & 1 & 1 & IV \\
\hline Campanula trachelium & + & . & . & . & + & . & . & . & . & . & I \\
\hline Scilla bifolia & . & . & . & . & . & . & . & . & + & + & I \\
\hline \multicolumn{12}{|l|}{ Inne (Others) } \\
\hline \multicolumn{12}{|l|}{ Drzewa i krzewy (Trees and shrubs): } \\
\hline Quercus robur a & 2 & + & 1 & 1 & 2 & 3 & 2 & 2 & . & 2 & $\mathrm{~V}$ \\
\hline Quercus robur c & . & . & . & . & . & + & + & + & . & . & II \\
\hline Sambucus nigra b & 2 & 1 & 1 & 1 & . & 2 & 2 & 1 & 2 & 1 & $\mathrm{~V}$ \\
\hline \multicolumn{12}{|l|}{ Rośliny zielne (Herbs): } \\
\hline Anthriscus nitida & 2 & + & 1 & + & + & + & + & + & + & . & $\mathrm{V}$ \\
\hline Oxalis acetosella & + & + & . & + & + & . & + & + & + & + & IV \\
\hline Dryopteris carthusiana & + & + & + & 1 & . & + & + & 1 & . & . & IV \\
\hline Ajuga reptans & . & . & + & 1 & + & . & + & . & + & + & III \\
\hline Chaerophyllum aromaticum & + & + & . & + & . & . & . & + & . & . & II \\
\hline Glechoma hirsuta & . & + & + & . & . & + & . & . & . & . & II \\
\hline Rubus hirtus & . & . & . & + & . & . & + & . & . & . & I \\
\hline
\end{tabular}

Sporadyczne (Sporadic): Drzewa i krzewy (Trees and shrubs): Ch.All. Carpinion betuli: Tilia cordata a (5) 2; Ch.O. Fagetalia sylvaticae: Ulmus laevis b (7) 1; Ch.Cl. Querco-Fagetea: Acer campestre a (2) 1, Alnus glutinosa a (6) 1. Inne (Others): Quercus rubra a (8) 1. Rośliny zielne (Herbs): Ch.Cl. Querco-Fagetea: Brachypodium sylvaticum (8) 1, Poa nemoralis (2). Inne (Others): Veratrum lobelianum (8) 1, Athyrium filix-femina (1), Campanula rapunculoides (3), Geum urbanum (5), Maianthemum bifolium (3), Melandrium rubrum (7).

położonymi buczynami, swój udział zaznaczyły w nim również gatunki należące do związku Fagion (Fagus sylvatica, Symphytum cordatum). Odnotowano 20 gatunków z rzędu Fagetalia, z których aż 11 (m.in.: Galeobdolon luteum, Pulmonaria obscura, Lilium martagon, Asarum europaeum) osiagało V stopień stałości oraz znaczne procentowe pokrycie (Tab. 1). Liczne były również gatunki z klasy Querco-Fagetea (12), ale ich pokrycie, z wyjątkiem Aegopodium podagraria, było znacznie mniejsze. Z 16 gatunków towarzyszących większe 


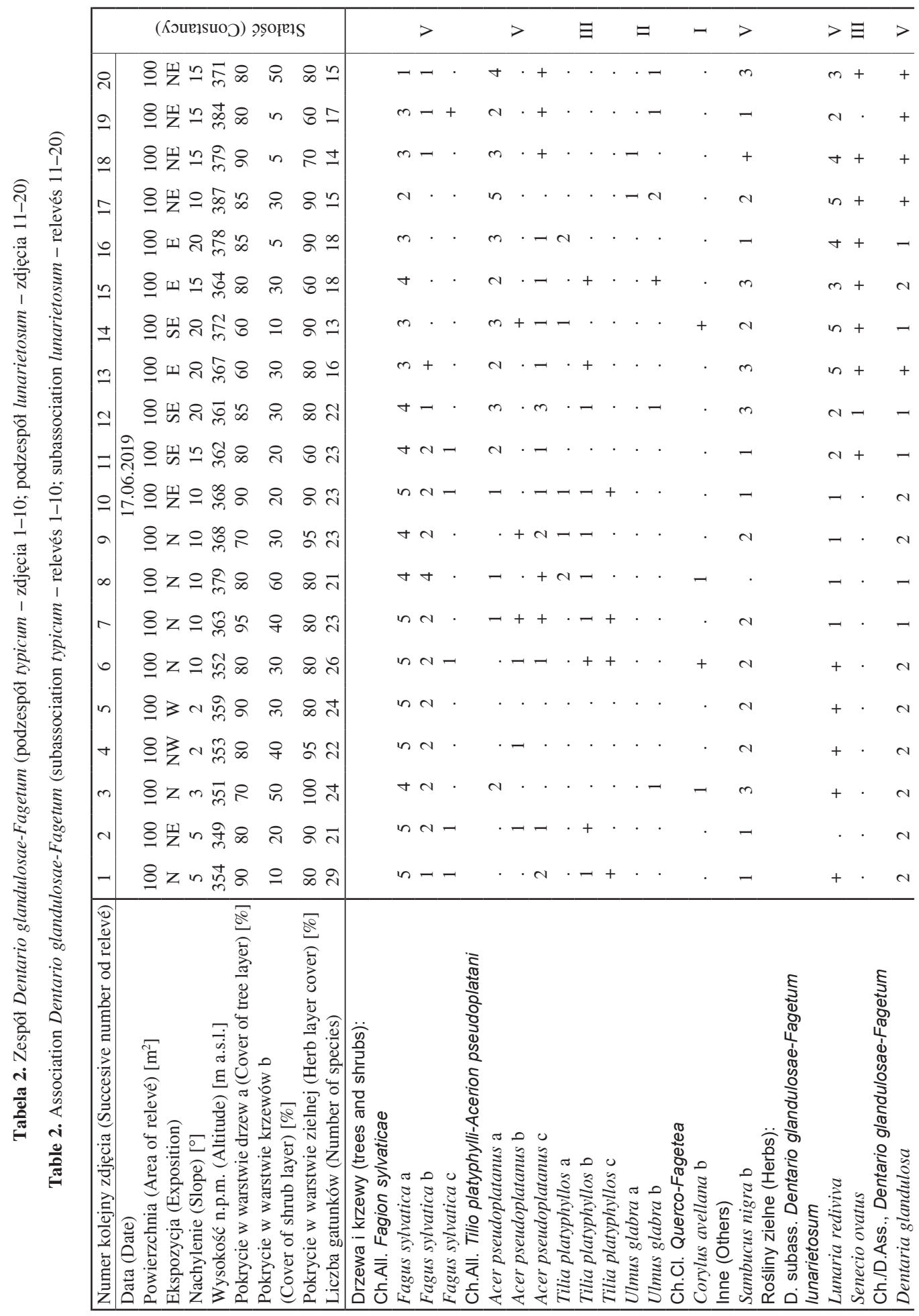



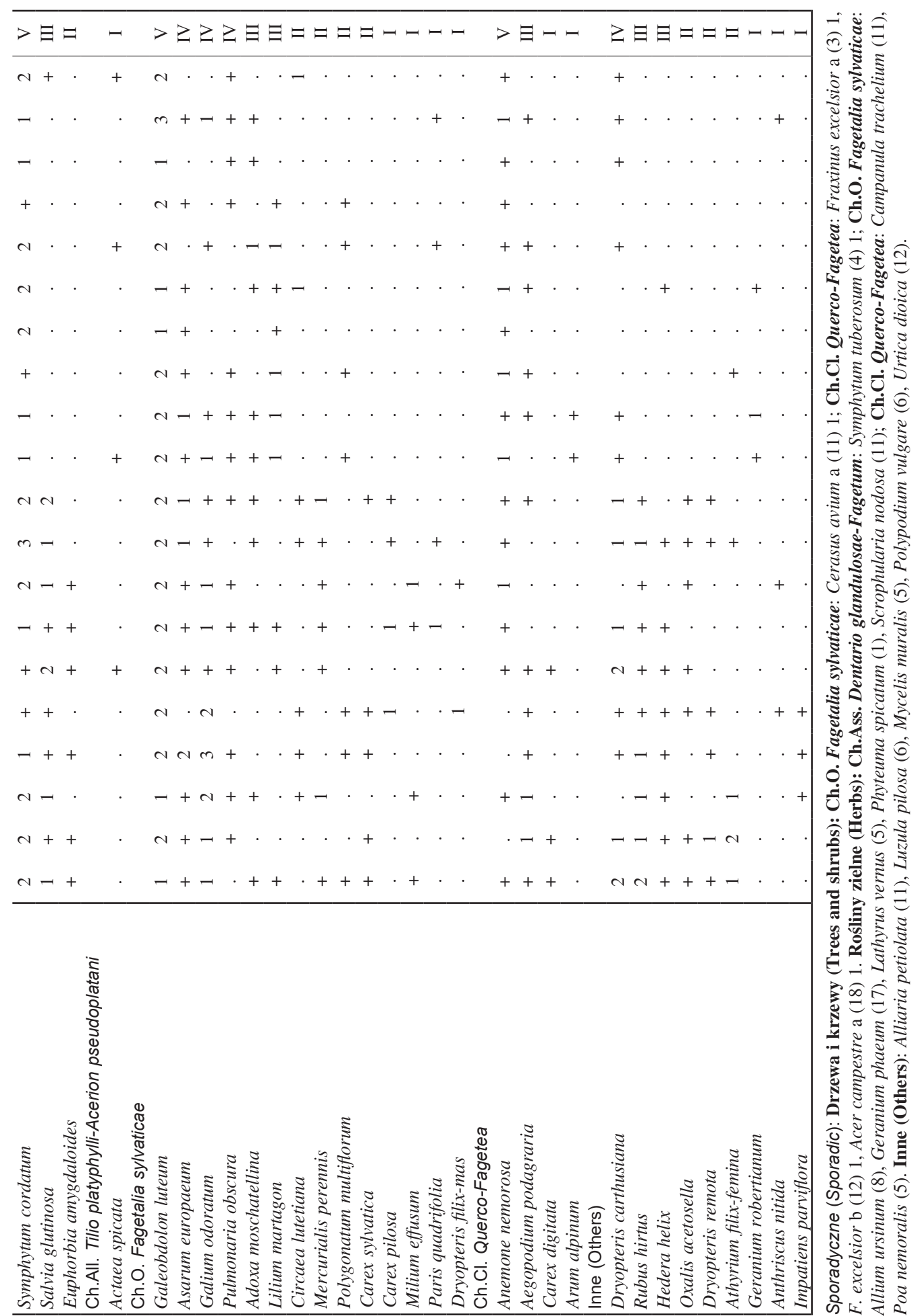
znaczenie miały Quercus robur w drzewostanie i Sambucus nigra w warstwie krzewów, pozostałe gatunki występowały na ogół sporadycznie.

W wyżej położonych partiach Lasu Hrabeńskiego, na stokach o lekkim lub umiarkowanym nachyleniu $\left(2-10^{\circ}\right)$ i zróżnicowanej ekspozycji (N, NE, W, NW), w których częstą formą terenu są doliny wciosowe i debrza, występuje podzespół Dentario glandulosae-Fagetum typicum. Odnotowano w nim 46 gatunków roślin naczyniowych (od 21 do 29 gatunków w zdjęciach, średnio 24) (Tab. 2, zdjęcia 1-10). W warstwie drzew, której średnie pokrycie wyniosło $82,5 \%$, najwyższe stopnie ilościowości osiagał Fagus sylvatica ze związku Fagion, a jego domieszkę stanowiły Acer pseudoplatanus i Tilia platyphyllos należące do związku Tilio platyphylli-Acerion. Warstwę krzewów, o średnim pokryciu równym $30 \%$, budowały głównie podrosty wymienionych gatunków drzew, a także Sambucus nigra i sporadycznie Corylus avellana. W runie, którego średnie pokrycie wynosiło $87 \%$, największe stopnie ilościowości miały gatunki charakterystyczne dla zespołu - Dentaria glandulosa i Symphytum cordatum. Towarzyszyły im gatunki wyróżniające dla żyznych buczyn karpackich: Lunaria rediviva, Salvia glutinosa, Euphorbia amygdaloides. Licznie reprezentowany był także rząd Fagetalia (16 gatunków), ale tylko Galeobdolon luteum, Asarum europaeum i Galium odoratum występowały obficiej. Odnotowano 6 gatunków charakterystycznych dla klasy Querco-Fagetea, jednak miały one niewielkie pokrycie. Spośród 12 gatunków towarzyszących znaczny udział miał Sambucus nigra w warstwie krzewów oraz Dryopteris carthusiana i Rubus hirtus w runie.

W najwyższych partiach wzgórza, na stokach o największym nachyleniu (10-20) i zróżnicowanej ekspozycji (SE, E, NE) wykształcił się podzespół Dentario glandulosae-Fagetum lunarietosum. Łącznie rosło w nim 37 gatunków, z czego w zdjęciach fitosocjologicznych notowano od 13 do 23 gatunków (średnio 17) (Tab. 2, zdjęcia 11-20). Ze względu na znaczne nachylenie oraz duży udział rumoszu skalnego, żadna z warstw zbiorowiska nie osiagała pełnego zwarcia. W warstwie drzew, której średnie pokrycie wynosiło 78,5\%, współdominowały Fagus sylvatica i Acer pseudoplatanus, zaś pozostałe gatunki drzew (Tilia platyphyllos, Ulmus glabra, Cerasus avium) występowały sporadycznie. Słabo wykształconą warstwę krzewów (średnie pokrycie 21,5\%) tworzył głównie Sambucus nigra z domieszką podrostu drzew. W runie (średnie pokrycie 76\%) w większości zdjęć fitosocjologicznych dominowała Lunaria rediviva - gatunek charakterystyczny dla podzespołu, natomiast drugi gatunek wyróżniający - Senecio ovatus - osiągał niewielkie pokrycie. Duże znaczenie w strukturze zbiorowiska miały gatunki charakterystyczne dla żyznej buczyny karpackiej: Dentaria glandulosa i Symphytum cordatum. Spośród 12 taksonów należących do rzędu Fagetalia licznie występował tylko Galeobdolon luteum. Udział gatunków towarzyszących, z wyjątkiem Sambucus nigra, był sporadyczny.

Wszystkie omawiane zbiorowiska roślinne odznaczały się dobrze zachowanym starodrzewem, wielogatunkowym drzewostanem oraz niezaburzonym i bogatym gatunkowo runem z gatunkami charakterystycznymi. O dobrym stanie zachowania siedlisk świadczy także obecność 52 gatunków wskaźnikowych dla starych lasów (m.in.: Aposeris foetida, Asarum europaeum, Euphorbia amygdaloides, Paris quadrifolia, Polygonatum multiflorum, Pulmonaria obscura), które na ogół występowały bardzo licznie w każdym zbiorowisku i pełniły ważną rolę w strukturze warstwy roślin zielnych. Wartość przyrodniczą tych podzespołów podnosi 
także obecność gatunków chronionych: 1 objęty ochroną ścisłą (Lilium martagon) oraz 6 objętych ochroną częściową (Arum alpinum, Daphne mezereum, Milium effusum, Primula elatior, Scilla bifolia, Veratrum lobelianum). Wszystkie gatunki chronione, z wyjątkiem Arum alpinum, występowały licznie, ale najliczniejsza była populacja lilii złotogłów (około 1500 osobników), która najobficiej rosła w podzespole Tilio-Carpinetum typicum.

\section{DYSKUSJA}

Zespół Tilio-Carpinetum obejmuje mezofilne, subkontynentalne lasy dębowo-grabowe strefy środkowoeuropejskiej, rosnące głównie na obszarze Polski. Ich drzewostan tworzą Carpinus betulus, Quercus robur i Tilia cordata. Stałym elementem warstwy krzewów jest Corylus avellana, a warstwy zielnej Carex pilosa (MATUSZKIEWICZ 2008; NovÁK i in. 2020). W Karpatach Tilio-Carpinetum jest zonalnym zbiorowiskiem leśnym piętra pogórza. Według TraczyKa (1962) grądy z terenu południowej Polski należą do małopolskiej odmiany zespołu Tilio-Carpinetum, która wyróżnia się obecnością gatunków górskich (m.in.: Abies alba, Acer pseudoplatanus, Fagus sylvatica, Dentaria glandulosa, Hedera helix, Primula elatior, Salvia glutinosa). Odmiana ta nawiązuje do zespołu Carici pilosae-Carpinetum występującego wzdłuż południowej krawędzi Zachodnich i Wschodnich Karpat, która charakteryzuje się częstszym występowaniem gatunków ciepłolubnych oraz mniejszym udziałem roślin przywiązanych do siedlisk chłodniejszych (Dzwonko 1986; SLEZÁK i in. 2011). Oba syntaksony mają jednak długą listę gatunków wspólnych, a ich podobieństwo najbardziej uwidacznia się w strukturze warstwy drzew (zazwyczaj dominantem jest Carpinus betulus) i krzewów (Corylus avellana). Bardzo często w runie tych zespołów dominuje Carex pilosa w towarzystwie takich roślin, jak: Stellaria holostea, Dactylis polygama, Polygonatum multiflorum (SLEZÁK i in. 2011). Dlatego autorzy najnowszej klasyfikacji lasów grabowych Europy Środkowej zalecają włączenie niektórych grądów występujących w południowej Polsce do zespołu Carici pilosae-Carpinetum (NovÁK i in. 2020).

Grądy Lasu Hrabeńskiego odznaczają się dużym zróżnicowaniem gatunkowym, w tym licznym udziałem gatunków charakterystycznych, dlatego zaklasyfikowano je do podzespołu Tilio-Carpinetum typicum. Podzespół typowy został opisany z wielu niżej położonych regionów Karpat (ŚwIĘs 1982a, b; RÓżAŃSKI 1987 i in.; KoZŁOWSKa 2000; TOWPASZ \& Stachurska-SwaKoń 2010). MedweCKA-Kornaś i in. (1987) wyróżniają dodatkowo dwie postacie tego syntaksonu: typową ze Stellaria holostea oraz postać z Galeobdolon luteum i Aegopodium podagraria. Zgodnie z klasyfikacją Dzwonki (1986) grąd na badanym terenie nawiązuje do pododmiany wschodniokarpackiej ze względu na znaczny udział w runie Aposeris foetida (Dzwonko 1977, 1986). Występowanie tego gatunku w grądach zostało również potwierdzone z Pogórza Strzyżowskiego (TowPASz \& STAchursKa-SwaKOŃ 2010) i Dynowskiego (WóJCIK i in. 2016).

Lasy bukowe i bukowo-jodłowe są charakterystyczne dla Karpat i regionów przyległych (MATUSZKiewicz 2008; Willner i in. 2017). W Polsce zespół Dentario glandulosaeFagetum swoim zasięgiem obejmuje obie prowincje karpackie oraz znaczną część Wyżyn 
Polskich. Buczyny preferują siedliska stosunkowo chłodne i wilgotne. Są zbiorowiskiem zonalnym dla regla dolnego na wysokościach od 540 do 1150 m n.p.m. (MATUSzKIEwICZ 2008). W niższych położeniach ich występowanie uwarunkowane jest lokalnym układem siedliska (m.in. chłodniejszym mikroklimatem i wystawą północną) i ma charakter ekstrazonalny (TOWPASz 1990; WóJCIK \& KostRAKIEWICZ-GIERAŁT 2020). W przypadku buczyn można również wykazać geograficzną zmienność, gdyż w Karpatach występują cztery lokalne odmiany zespołu Dentario glandulosae-Fagetum: tatrzańska, pienińska, zachodniokarpacka oraz wschodniokarpacka (DzwONKO 1986). Chociaż istnieje szereg opracowań dotyczących zróżnicowania lasów bukowych ze związku Fagion, nadal trwają dyskusje nad ich klasyfikacją (WILLNER i in. 2017). Najszerzej rozpowszechniony w Karpatach jest podzespół typowy Dentario glandulosae-Fagetum typicum (GRODZIŃSKA \& PANCER-KoteJOWA 1965; STASZKIEWICZ 1973; Święs 1982a, b; RóżAŃSKI i in. 1987; KoZŁowsKA 2000). Występuje w nim szereg gatunków z rzędu Fagetalia osiągających swoje optimum w reglu dolnym. Typowa postać żyznej buczyny karpackiej posiada drzewostan zdominowany przez Fagus sylvatica, którego domieszkę stanowią Abies alba i Acer pseudoplatanus. Warstwa krzewów w tym zbiorowisku jest na ogół uboga, budują ją głównie podrosty drzew. W bogatym gatunkowo runie obecne są gatunki charakterystyczne dla buczyn, takie jak: Dentaria glandulosa, D. bulbifera i Symphytum cordatum. W miejscach wilgotnych i żyznych wykształca się podzespół z miesiącznicą trwałą Dentario glandulosae-Fagetum lunarietosum. Centrum jego występowania obejmuje obszar Karpat Wschodnich (Dzwonko 1977, 1986) i terenów przyległych należących już do Beskidu Niskiego (GRODzIŃSKA \& PANCER-KoTEJOwA 1965; STASZKIEWICZ 1973; ŚwIĘS 1982a, b), natomiast bardzo rzadko i w postaci rozproszonych płatów obecny jest także w Karpatach Zachodnich (BODZIARCZYK \& PANCER-Koteja 2004; WiLCZEK 2006; TOWPASZ \& STACHURSKA-SwAKOŃ 2010).

Na obszarze Lasu Hrabeńskiego występowanie buczyn miało charakter ekstrazonalny. Typową postać zespołu stwierdzono w wyższych partiach wzgórz, na stokach o lekkim nachyleniu i ekspozycji z sektora północnego. Podobne siedliska zajmował podzespół z miesiącznicą trwałą, ale były to miejsca wilgotniejsze i znacznie bardziej nachylone. Również w innych rejonach Karpat podzespół Dentario glandulosae-Fagetum lunarietosum stwierdzono na stromych stokach o wystawie północnej (GRODZIŃSKA \& PANCER-KoteJOWA 1965; TOWPASZ \& STACHURSKA-SwAKOŃ 2010). Obszar Natura 2000 Las Hrabeński został powołany w celu ochrony trzech siedlisk przyrodniczych, w tym siedliska 9180 (jaworzyna z miesiącznicą trwałą Lunario-Aceretum) występującego na najbardziej nachylonych stokach w południowo-zachodniej części kompleksu leśnego (ŁUCZAJ 2011). Jednak analiza zdjęć fitosocjologicznych z tej części obszaru (Tab. 2, zdjęcia 11-20) wykazała, że rośnie tutaj podzespół Dentario glandulosae-Fagetum lunarietosum. Jego skład gatunkowy (znaczny udział Acer pseudoplatanus w drzewostanie oraz dominacja Lunaria rediviva w runie) nawiązuje do jaworzyny z miesiącznicą Lunario-Aceretum, ale brak pozostałych gatunków charakterystycznych nie pozwala zaklasyfikować go do siedliska 9180.

Pomimo iż przeważająca część badanego kompleksu leśnego (ponad 94\% powierzchni) położona jest na gruntach Państwowego Gospodarstwa Leśnego Lasy Państwowe - i podlega regularnym działaniom gospodarczym - obszar ten posiada wysokie walory przyrodnicze. Wszystkie scharakteryzowane zbiorowiska roślinne (Tilio-Carpinetum typicum, 
Dentario glandulosae-Fagetum typicum i Dentario glandulosae-Fagetum lunarietosum) są zachowane w dobrym stanie i posiadają charakterystyczną dla siebie kombinację gatunkową, a także wysokie bogactwo gatunkowe, którego dopełnienie stanowią gatunki chronione oraz wskaźnikowe dla starych lasów.

\section{LITERATURA}

Bodziarczyk J. \& Pancer-Koteja E. 2004. Mezofilne i ciepłolubne lasy jodłowo-bukowe Pienińskiego Parku Narodowego. - Studia Naturae 49: 87-121.

Braun-Blanquet J. 1964. Pflanzensoziologie. Grundzüge der Vegetationskunde. s. 865. Springer Verlag, Wien, New Jork.

DYREKTYwa 1992. Dyrektywa Rady 92/43/EWG z dnia 21 maja 1992 r. w sprawie ochrony siedlisk przyrodniczych oraz dzikiej fauny i flory (Dz.U. UE.L. $1992 \mathrm{Nr}$ 206, poz. 7).

Dzwonko Z. 1977. Zbiorowiska leśne Gór Słonnych (polskie Karpaty Wschodnie). - Fragmenta Floristica et Geobotanica 23(2): 161-200.

Dzwonko Z. 1986. Klasyfikacja numeryczna zbiorowisk leśnych polskich Karpat. - Fragmenta Floristica et Geobotanica 30(2): 93-167.

Dzwonko Z. 2007. Przewodnik do badań fitosocjologicznych. s. 302. Wydawnictwo Sorus, Poznań - Kraków.

Dzwonko Z. \& Loster S. 2001. Wskaźnikowe gatunki roślin starych lasów i ich znaczenie dla ochrony przyrody i kartografii roślinności. - W: E. Roo-ZIELIŃsKA \& J. Solon (red.), Typologia zbiorowisk i kartografia roślinności w Polsce - rozważania nad stanem współczesnym. - Prace Geograficzne 178: 119-132.

Dzwonko Z. \& Zemanek B. 1976. Roślinność rezerwatu Góra Sobień koło Manasterca (Polskie Karpaty Wschodnie). - Ochrona Przyrody 41: 179-204.

GrodzińsKa K. \& Pancer-Kotejowa E. 1965. Zbiorowiska leśne Pasma Bukowicy w Beskidzie Niskim. - Fragmenta Floristica et Geobotanica 11(4): 563-599.

Kondracki J. 2011. Geografia regionalna Polski. s. 441. Wydawnictwo Naukowe PWN, Warszawa.

KozŁowska A. 2000. The forest communities in the Przemyśl Foothils, south-east Poland. - Fragmenta Floristica et Geobotanica 45(1-2): 345-372.

Łuczaj Ł. 2011. Las Hrabeński. - W: D. RogaŁa \& A. Marcela (red.), Obszary Natura 2000 na Podkarpaciu, s. 174-177. Regionalna Dyrekcja Ochrony Środowiska w Rzeszowie, Rzeszów.

Matuszkiewicz J. M. 2008. Zespoły leśne Polski. s. 358. Wydawnictwo Naukowe PWN, Warszawa.

MatuszKIEWICZ W. 2001. Przewodnik do oznaczania zbiorowisk roślinnych Polski. s. 537. Wydawnictwo Naukowe PWN, Warszawa.

MedweCKa-Kornaś A. 1976. Szata roślinna dorzecza Białej Dunajcowej - W: Z. CZEPPE (red.), Wartości środowiska geograficznego dorzecza Białej Dunajcowej i zagadnienia jego ochrony. - Studia Ośrodka Dokumentacji Fizjograficznej 5: 137-167.

Medwecka-Kornaś A., Towpasz K. \& Gawroński S. 1988. Dolina Wierzbanówki: 17. Zespoły leśne. - Zeszyty Naukowe Uniwersytetu Jagiellońskiego, Prace Botaniczne 17: 99-123.

MichaLiK S. 2009. Zbiorowiska roślinne - W: A. GóRECKI \& B. ZEMANEK (red.), Magurski Park Narodowy - monografia przyrodnicza, s. 96-120. Magurski Park Narodowy, Krempna-Kraków.

Mirek Z., PięKoś-Mirkowa H., Zając A. \& ZająC M. 2002. Flowering plants and pteridophytes of Poland. A checklist. - W: Z. MireK (red.), Biodiversity of Poland. 1, s. 442. W. Szafer Institute of Botany, Polish Academy of Sciences, Kraków. 
Novák P., Willner W., Zukal D., Kollár J., RolečEk J., Świerkosz K., Ewald J., Wohlgemuth T., CSIKY J., ONYSHChENKo V. \& ChYtRY M. 2020. Oak-hornbeam forests of central Europe: a formalized classification and syntaxonomic revision. - Preslia 92: 1-34.

RozPORZĄDZENIE Ministra Środowiska z dnia 9 października 2014 r. w sprawie ochrony gatunkowej roślin (Dz. U. 2014, poz. 1409).

Różański W., Pancer-Kotejowa E. \& Grodzińska K. 1993. Vegetation of the Ratanica Watershed (Carpathian Foothills, Southern Poland). - Ekologia Polska 41(3-4): 347-374.

Różański W., Filkowa B., Kobak L., Koczwańska J., Lesiński J., Szwagrzyk J. \& Tarko G. 1987. Zróżnicowanie zbiorowisk leśnych występujących na Pogórzu Wielickim i w przyległej części Beskidów. - Zeszyty Naukowe Akademii Rolniczej im. H. Kołłątaja w Krakowie 215, Sesja Naukowa 17: 221-231.

SlezÁK M., HegedüŠová K. \& SenKo D. 2011. Syntaxonomy and ecology of forest vegetation in the Štiavnické vrchy Mts (Central Slovakia). - Acta Societatis Botanicorum Poloniae 80(2): 115-127.

STACHURSKA A. 1995. Zróżnicowanie zbiorowisk lasu „Ligęzianka” (Pogórze wielickie). - Zeszyty Naukowe Uniwersytetu Jagiellońskiego, Prace Geograficzne 100: 149-160.

Stachurska A. 1998. Zbiorowiska leśne północno-wschodniej części Pogórza Wielickiego (Karpaty Zachodnie). - Zeszyty Naukowe Uniwersytetu Jagiellońskiego, Prace Botaniczne 30: 1-78.

StaszKiewicz J. 1973. Zbiorowiska leśne okolic Szymbarku (Beskid Niski). - Dokumentacja Geograficzna 1: 73-97.

ŚwIĘS F. 1982a. Charakterystyka geobotaniczna lasów Beskidu Niskiego. Analiza i synteza. s. 108. Uniwersytet Marii Curie-Skłodowskiej, Wydział biologii i Nauk o Ziemi, Lublin.

ŚWIĘS F. 1982b. Geobotaniczna charakterystyka lasów dorzeczy Jasiołki i Wisłoka w Beskidzie Niskim. - Biblioteka Przemyska 10: 1-107.

TACiK T., Zającówna M. \& ZarzYcKi K. 1957. Z zagadnień geobotanicznych Beskidu Niskiego. - Acta Societatis Botanicorum Poloniae 26(1): 17-43.

TowPASz K. 1990. Charakterystyka geobotaniczna Pogórza Strzyzowskiego. - Zeszyty Naukowe Uniwersytetu Jagiellońskiego, Rozprawy habilitacyjne 178: 1-242.

Towpasz K. \& StachursKa-Swakoń A. 2008. Alder-ash and willow communities and their diversity in the Pogórze Strzyżowskie Foothills (Western Carpathians). - Acta Societatis Botanicorum Poloniae 77(4): 327-338.

TOWPASZ K. \& STAChURSKA-SwaKoń A. 2010. Zróżnicowanie zbiorowisk leśnych ze związków: Carpinion betuli i Fagion sylvaticae na Pogórzu Strzyżowskim (Karpaty Zachodnie). - Fragmenta Floristica et Geobotanica Polonica 17(2): 315-359.

TRACZYK T. 1962. Materiały do geograficznego zróżnicowania grądów w Polsce. - Acta Societatis Botanicorum Poloniae 31(4): 621-635.

WILCZEK Z. 2006. Fitosocjologiczne uwarunkowania ochrony przyrody Beskidu Śląskiego (Karpaty zachodnie). s. 223. Wydawnictwo Uniwersytetu Śląskiego, Katowice.

Willner W., Jiménez-Alfaro B., Agrillo E., Biurrun I., Campos J.A., Čarni A., Casella L., Csiky J., Čušterevska R. Didukh Y.P., Ewald J., Jandt U., Jansen F., KąCKi Z., KavgaCi A., Lenoir J., MarinŠEk A., Onyshchenko V., Rodwell J.S., Schaminée J.H.J., Šibík J., ŠKVorC Ž., Svenning J.-C., Tsiripidis I., Turtureanu P.D., Tzonev R., Vassilev K., Venanzoni R., Wohlgemuth T. \& CHYTRY M. 2017. Classification of European beech forests: a Gordian Knot? - Applied Vegetation Science 20: 494-512.

Wóscik T. \& Ziaja M. 2015. Zbiorowiska roślinne wzgórza Kamieniec na Pogórzu Dynowskim (Karpaty Zachodnie). - Parki Narodowe i Rezerwaty Przyrody 34(2): 57-74. 
WósciK T. \& ZiAJA M. 2017. Występowanie Lilium martagon L. w buczynie karpackiej Dentario glandulosae-Fagetum w rezerwacie Góra Chełm na Pogórzu Strzyżowskim (Karpaty Zachodnie). - Parki Narodowe i Rezerwaty Przyrody 36(6): 65-76.

WóJCIK T. \& KostrakiewicZ-GIERAŁT K. 2020. Trait variability in the rare plant species Arum alpinum in Carpathian beech forest Dentario glandulosae-fagetum (Western Carpathians, Poland). - Polish Journal of Ecology 68(1): 23-36.

Wójcik T., Rogus A. \& Ćwik A. 2016. Zbiorowiska roślinne lasu „Św. Roch” w Rzeszowie (Pogórze Dynowskie). - Fragmenta Floristica et Geobotanica Polonica 23(1): 101-120.

\section{SUMMARY}

Research was carried out in 2019 in the Las Hrabeński PLH 180039 Natura 2000 area, located in the Pogórze Bukowskie foothills (Western Carpathians) in the southern part of Podkarpackie Province (Kondracki 2011). This relatively small and isolated forest complex has a surface area of 125.6 ha (ŁUCZAJ 2011). It was established as the Las Hrabeński PLH 180039 Natura 2000 area to protect a well-preserved forest ecosystem comprising three natural habitats from Annex I of the Habitats Directive: 9170 TilioCarpinetum, 9130 Dentario glandulosae-Fagetum and 9180 Lunario-Aceretum (EuCZAJ 2011).

Phytosociological studies employed the BRAUN-BLANQUET (1964) method. Thirty phytosociological relevés were made in all three types of natural habitat. The syntaxonomic classification follows that proposed by Matuszkiewicz (2001) and also regional studies (Dzwonko 1977, 1986; TowPASZ \& STACHURSKASWAKOŃ 2010). Vascular plant nomenclature was adopted from MiREK et al. (2002). Legally protected species were listed in accordance with the Regulation of the Minister of the Environment (REGULATION 2014), and the old-forest indicator species were identified as in DZWONKo and LOSTER (2001).

Analysis of the 30 phytosociological relevés showed three plant communities at subassociation rank: Tilio-Carpinetum typicum, Dentario glandulosae-Fagetum typicum and Dentario glandulosae-Fagetum lunarietosum. Tilio-Carpinetum typicum developed on slight slopes $\left(2-3^{\circ}\right)$ in the lower part of the hills. In terms of relief, the area is rich in concave landforms. The tree stand was found to cover 70-95\% (mean cover 87.8\%), and was dominated by Carpinus betulus with admixture of Acer pseudoplatanus, A. campestre, Ulmus laevis and Tilia cordata. The abundant understory (mean cover 34\%) was composed of tree saplings and numerous shrubs: Sambucus nigra, Daphne mezereum, Padus avium, Lonicera xylosteum and Corylus avellana. The uniqueness of the community is evidenced by the well-developed, rich, diverse herbaceous vegetation with up $100 \%$ cover. In total, 57 vascular plant species were noted in the entire community, and from 28 to 40 plants were identified in the phytosociological relevés. There were many typical hornbeam forest species, including Ranunculus cassubicus and Carex pilosa, which are characteristic for the Tilio-Carpinetum association, and Carpinus betulus, Tilia cordata, Stellaria holostea and Dactylis polygama from the Carpinion betuli alliance.

The Dentario glandulosae-Fagetum typicum subassociation was identified on slopes with a slight or moderate incline $\left(2-10^{\circ}\right)$ and varied exposure in the higher parts of Las Hrabeński Forest. It comprised 46 vascular plant species, with 21-29 species identified in the relevés. The highest abundance in the tree stand (mean cover $82.5 \%$ ) was recorded for Fagus sylvatica from the Fagion alliance; Acer pseudoplatanus and Tilia platyphyllos from the Tilio platyphylli-Acerion alliance were admixtures. The understory (mean cover $30 \%$ ) was mainly composed of saplings of the abovementioned tree species, as well as Sambucus nigra and sporadically Corylus avellana. The undergrowth layer (mean cover $87 \%$ ) was dominated by indicator species of the association: Dentaria glandulosa and Symphytum cordatum. They were accompanied by species typical of fertile Carpathian beech forests: Lunaria rediviva, Salvia glutinosa and Euphorbia amygdaloides.

The slopes with the largest incline $\left(10-20^{\circ}\right)$ and varied exposure in the highest parts of the hill were covered by the Dentario glandulosae-Fagetum lunarietosum subassociation. In total, it comprised 37 species, with 13-23 species recorded in the relevés. The tree stand (mean cover 78.5\%) was co-dominated by Fagus sylvatica and Acer pseudoplatanus, whereas other tree species (Tilia platyphyllos, Ulmus glabra, Cerasus avium) occurred sporadically. The poorly developed understory (mean cover $21.5 \%$ ) was mainly formed by 
Sambucus nigra with admixture of tree saplings. As shown by the relevés, the undergrowth (mean cover 76\%) was dominated by Lunaria rediviva, the major species of the subassociation, whereas the other differential species Senecio ovatus reached low cover. Species characteristic of fertile Carpathian beech forest, Dentaria glandulosa and Symphytum cordatum, had a considerable share in the community structure.

It should be underlined that all the plant communities analysed in this study had a well-preserved old tree stand, a multi-species, diversified stand structure, and naturally developed and species-rich undergrowth composed of characteristic species. The good condition of the habitats is evidenced by the presence of 52 old-forest indicator species and 7 protected species (Arum alpinum, Daphne mezereum, Lilium martagon, Primula elatior, Scilla bifolia, Veratrum lobelianum).

Wptynęto:16.07.2020 r.; przyjęto do druku: 16.12.2020 r. 